\title{
Characteristics of consolidation settlements and sedimentary environments of the late Pleistocene-Holocene deposits in the Mekong Delta and Ho Chi Minh City, Vietnam
}

\author{
Minh Hoang Truong ${ }^{1,2}$ and Dinh Thanh Nguyen $^{1,2}$ \\ ${ }^{1}$ Department of Engineering Geology - Environmental Geology, University of Science, \\ 227 Nguyen Van Cu Street, District 5, Ho Chi Minh City, Vietnam \\ ${ }^{2}$ Vietnam National University Ho Chi Minh City, Linh Trung Ward, Thu Duc District, \\ Ho Chi Minh City, Vietnam \\ Correspondence: Minh Hoang Truong (tmhoang@hcmus.edu.vn)
}

Published: 22 April 2020

\begin{abstract}
The report displays the characteristics of sedimentary environments, consolidation and consolidation settlements of the late Pleistocene-Holocene deposits in the Mekong Delta (MD) and Ho Chi Minh City (HCMC), Vietnam. The report furthermore discusses the influences of sedimentary environments on the consolidation properties and the resulting complex and large consolidation settlements. They cause land subsidence and uneven settlements of foundations in HCMC and the MD. They have especially combined with the unsuitable plans, land use like land fill in the lower land, rivers and ponds in the delta and increase in sea level by the global climatic change. As a result, it is very difficult to improve waterlogged areas in HCMC and the MD by the rain and tide waters. It is also not easy to propose a standard strategy for the management, planning and construction of these areas.
\end{abstract}

\section{Introduction}

The Mekong Delta (MD), the largest delta in Vietnam, is located in southern Vietnam. The hydrology regimes in the MD and Ho Chi Minh City (HCMC) are influenced by the Mekong River system and by the Sai Gon and Dong Nai river systems, respectively, while the lower parts of both areas are significantly influenced by the East Sea (Fig. 1). In general, Holocene sediments cover about $96 \%$ of the area of the delta (Tran, 1993). The late Pleistocene-Holocene sediments/postglacial sediments/top sediment layers are mostly subjected to a stress increase due to construction, especially embankments or land fill in the lower land. The consolidation properties in the MD late Pleistocene-Holocene sediments change strangely: the overconsolidation ratio, OCR, decreases with depth in many places; it is mostly lower than 1 from 12 to $40 \mathrm{~m}$ according to soil investigation results obtained by engineering firms, possibly due to the low sample quality
(Man, 2003). The microstructure development level of Cantho clay is very high (Takemura et al., 2007). The sedimentary environments significantly affected the formation of the materials, macro and micro structures, and the orientation of geotechnical properties. The particular sedimentary conditions in the late Pleistocene-Holocene deposits can be reasonably estimated by the CPTU (piezo-cone penetrometer test) (Truong et al., 2011). Burland (1990) proposed a method for describing the structure level of natural clay in the delta by using the sedimentation compression line (SCL) and the intrinsic compression line (ICL). The structures of post-glacial sediments in the delta depend on both the depositional conditions and post-depositional processes. The ageing has a very important role in developing the microfabric of clay, increasing the resistance to the compression, and this resistance does not depend on the volume reduction due to creep. He also suggested that the ratio of the intrinsic swelling index, $C_{\mathrm{s}}^{*}$, to the undisturbed swelling index, $C_{\mathrm{s}}$, 


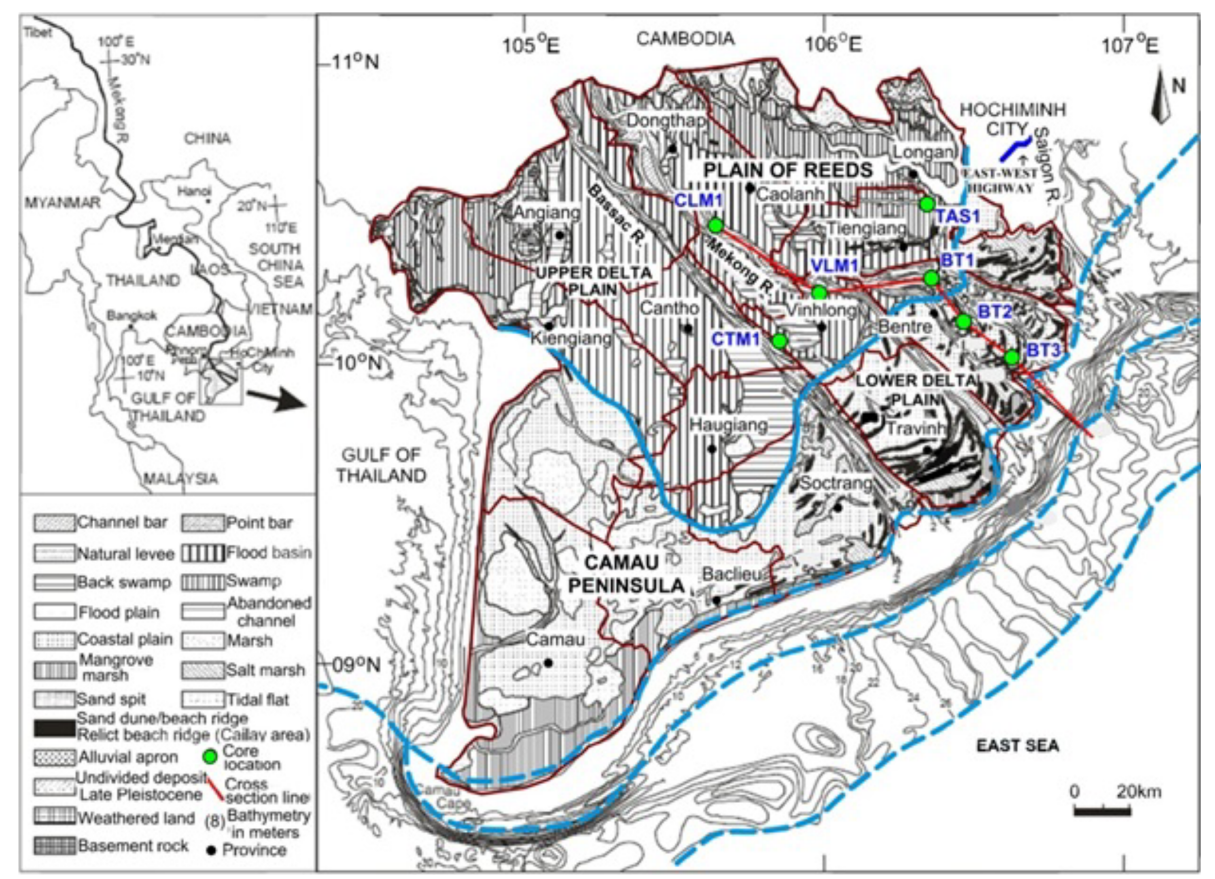

Figure 1. Map of the sedimentary environments of the MD and the location of HCMC (Ta et al., 2005) with a site investigation layout including the CLM1, VLM1, BT1, BT2, BT3, CTM1 and TAS1 sites.

$C_{\mathrm{s}}^{*} / C_{\mathrm{s}}$, could be a sensitive indicator of fabric and interparticle bonding in the natural soils. Each sedimentary facies was formed under a different environment and revealed typical geotechnical properties (Truong et al., 2011). Each sedimentary facies would be expected to possess typical consolidation properties which would result in different consolidation settlements. This hypothesis is analyzed in this article.

\section{Investigation program}

The survey associated the consolidation properties and the sedimentary geology on the post-glacial sediments. All in situ tests and sampling were carried out from the surface to the end of the post-glacial sediments and a part of the undifferentiated Pleistocene sediments.

\subsection{In situ tests, boring and sampling}

All in situ test sites occurred within $10 \mathrm{~m}$ from each of the original core sites. The symbols of the boreholes indicate therefore the location of additional site investigation (Fig. 1). A hydraulic type thin-walled tube sampler with a fixed piston was used to obtain soil samples. A stainless-steel sampling tube with $2 \mathrm{~mm}$ thickness, $85 \mathrm{~mm}$ inside diameter and $710 \mathrm{~mm}$ length was pushed into the ground by water pressure. The soil samples were maintained in the stainless-steel tube sampler and enveloped by the wet soft materials and stored in the wooden boxes. The OCR in cohesive soils was estimated from the CPTU results at the sites by the simple formula (1) with $k$ values in a range of 0.2 to 0.5 (Lunne et al., 1997; Truong et al., 2016).

The yield stress ratio is

$\mathrm{OCR}=k \cdot\left(\frac{q_{\mathrm{t}}-\sigma_{\mathrm{vo}}}{\sigma_{\mathrm{vo}}{ }^{\prime}}\right)$

where $\sigma_{\mathrm{vo}}$ and $\sigma_{\mathrm{vo}}^{\prime}$ are the total vertical stress and the effective vertical stress, and $q_{\mathrm{t}}$ is the cone resistance.

\subsection{Lab tests}

\subsubsection{Geotechnical engineering tests}

To evaluate the one-dimensional consolidation properties, incremental loading (IL) oedometer tests (Head, 1985b) were mainly conducted using the undisturbed and reconstituted samples. The constant rate of strain (CRS) consolidation tests (JGS, 2000) were also conducted on typical soil samples, which were obtained from each facies. The yield stresses $\sigma_{\mathrm{y}-\mathrm{IL}}{ }^{\prime}$ and $\sigma_{\mathrm{y}-\mathrm{CRS}}{ }^{\prime}$ were estimated from the IL and CRS results, and the yield stress ratio OCR $\left(\sigma_{\mathrm{y}}{ }^{\prime} / \sigma_{\mathrm{vo}}{ }^{\prime}\right)$ was calculated. The basic geotechnical properties (Head, 1985a) and unconfined compressive (UC) tests were conducted for both the undisturbed clay and the remolded clay to obtain the sensitivity, $S_{\mathrm{t}}$. The void index $I_{\mathrm{vo}}$ of the in situ void ratio $e_{0}$ was estimated using Eq. (2) (Burland, 1990), where $e_{100}^{*}$ and $e_{1000}^{*}$ are the void ratios of the intrinsic compression curve at $\sigma_{\mathrm{v}}^{\prime}=100$ and $1000 \mathrm{kPa}$, respectively. 



(B) VLM1 site

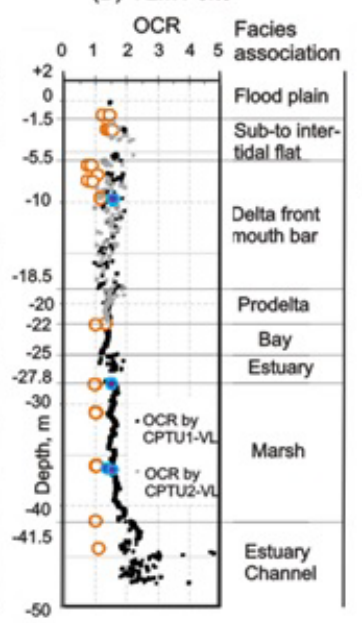

(E) BT3 site

OCR

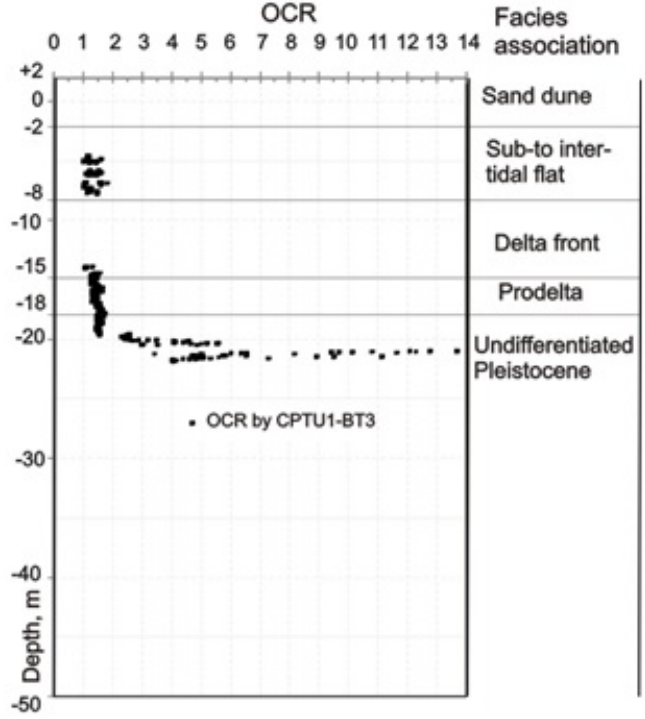

Figure 2. Values of OCR with depth from IL, CRS and CPTU tests for the cohesive soils at the CLM1, VLM1, BT1, BT2, and BT3 sites (Truong et al., 2016).

$$
I_{\mathrm{vo}}=\frac{e_{0}-e_{100}^{*}}{e_{100}^{*}-e_{1000}^{*}}
$$

\subsubsection{Clay minerals, ${ }^{14} \mathrm{C}$ ages}

The samples were individually inspected and photographed, and a detailed investigation plan was conducted for specific soil samples. The detailed soil profiles were determined. Various analyses of the sedimentary structures and properties were conducted. Radiocarbon dating of the organic material in some soil samples was performed by the Beta Analytic Radiocarbon Dating Lab. Clay mineral analyses based on Xray diffraction methods were performed using the D8 ADVANCE automatic system.

\subsubsection{Estimation of consolidation settlements}

The primary consolidation settlements were calculated using Eq. (3) for normally consolidated clays, in overconsolidated clays: Eq. (4) for $P_{0}+\Delta P \leq P_{\mathrm{c}}$ and Eq. (5) for $P_{0}+\Delta P>P_{\mathrm{c}}$ (Braja, 1998).

$$
\begin{aligned}
S & =\sum\left[\frac{C_{\mathrm{c}} H}{1+e_{0}} \log \left(\frac{P_{0(i)}+\Delta P_{(i)}}{P_{0(i)}}\right)\right], \\
S & =\frac{C_{\mathrm{s}} H}{1+e_{0}} \log \left(\frac{P_{0}+\Delta P}{P_{0}}\right), \\
s & =\frac{C_{\mathrm{s}} H}{1+e_{0}} \log \frac{P_{\mathrm{c}}}{P_{0}}+\frac{C_{\mathrm{c}} H}{1+e_{0}} \log \left(\frac{P_{0}+\Delta P}{P_{\mathrm{c}}}\right),
\end{aligned}
$$

where $C_{\mathrm{c}}$ is the compression index, $H$ is the height of the soil layer, $P_{0}$ is the effective overburden pressure, $\Delta P$ is the 


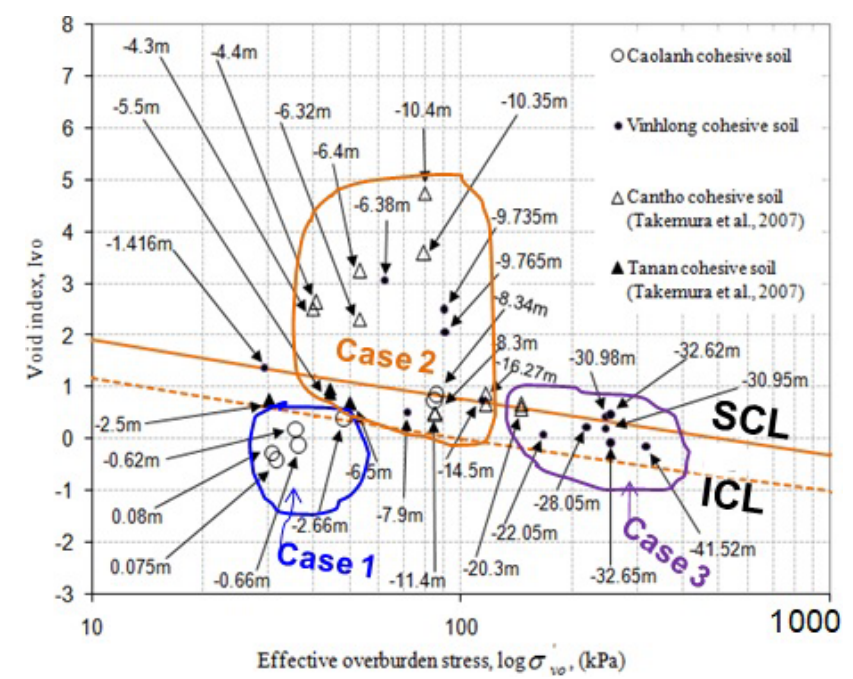

Figure 3. Relationship between the void indices $I_{\mathrm{vo}}$ and the effective overburden stress $\sigma_{\mathrm{vo}}{ }^{\prime}$ on the cohesive soils in the investigation sites (Truong et al., 2016).

embankment load pressure, $C_{\mathrm{s}}$ is the swell index, $e_{0}$ is the initial void ratio, and $P_{\mathrm{c}}$ is the preconsolidation pressure.

\section{Results and discussions}

\subsection{Consolidation, sedimentary environments}

The consolidation level of the argillaceous soil in each facies is interpreted by a combination of the environmental environments, formation mechanism, consolidation properties, ${ }^{14} \mathrm{C}$ age, and analysis of the TSS (thin soil section) and SEM images. They included three main broad cases, namely the surface sediment facies associations, the shallow sediment facies associations, and the deep sediment facies associations, and are presented as follows.

\subsubsection{Surface sediment facies associations}

Case 1 includes natural levee, flood plain, inter-tidal flat, and sub- to inter-tidal flat facies contacting the solar energy and air.

For the natural levee facies at the CLM1 site, the OCR values are notably large, from 6.1 to 2.2 (Fig. 2a). The $I_{\mathrm{v}}$ values lie well below the corresponding ICL, around and so less than zero despite the notably small values of ${\sigma_{\mathrm{vo}}}^{\prime}: 30$ to $40 \mathrm{kPa}$ (Fig. 3).

Hence, their consolidation levels can be medium to high. There are differences about the material supply, tidal influence, characteristics of the clay minerals, and age between the upper delta plain and lower delta plain (Truong, et al., 2016).

\subsubsection{Shallow sediment facies associations}

Case 2, the delta front facies with alternation of clay and sand seams, was created in the marine environment with high energy. The clay in the delta front facies is in the salt flocculation structure. In truth, according to Braja (1998), the clay that is in the salt flocculation structure is somewhat overconsolidated. Therefore, the OCR values on the delta front sediments are somewhat greater than 1 (Fig. 2). The $I_{\mathrm{vo}}$ values for the delta front cohesive soils at the VLM1 and CTM1 sites largely vary and lay well above the SCL (Burland, 1990) (Fig. 3). Conversely, for the homogenous cohesion soils in the other facies associations, the $I_{\mathrm{vo}}$ values are close to or below the SCL for the most of the plots (Fig. 3). The combination of the analyses allows us to infer that the consolidation levels of the delta front sediments are low to medium.

\subsubsection{Deep sediment facies associations}

Case 3 includes prodelta, bay, estuarine marine, sub- to intertidal flat, marsh, marsh/tidal flat, and estuary channel facies associations. They were recovered from greater depths and formed at an earlier stage than those of case 2, so they have been strongly subjected to ageing. Simultaneously, the pyrites are significantly recrystallized. Recrystallization tends to increase from the prodelta to estuary channel sediments (Truong et al., 2016). These results allow us to infer that the consolidation levels in the marsh and tidal flat sediments range from high to very high.

The ground continuously increased and the OCR values are never less than 1 (Fig. 2). And the overconsolidation is due to the cementation, recrystallization, and ageing.

\subsubsection{Undifferentiated Pleistocene sediment basement}

As a result, the undifferentiated Pleistocene and lag sediments are characterized by the stiff to hard, oxidized, yellowish gray silty sand and fine-medium sand bearing scattered quartz pebbles $0.5-1 \mathrm{~cm}$ in diameter and laterite, and thus heavy overconsolidation. The late PleistoceneHolocene sedimentary facies directly overlay the undifferentiated Pleistocene sediment basement with ages over $43400 \mathrm{yr}$ BP (Ta et al., 2002a, b). Values of OCR suddenly shift from the late Pleistocene-Holocene sediments to the lag deposit and then the undifferentiated Pleistocene sediment basement (Fig. 2b, c, and e). The appeared depths are 10 to $71 \mathrm{~m}$ from the ground surface. The undifferentiated Pleistocene sediment basement can be a great advantage for heavy structures.

\subsection{Consolidation settlements}

The preliminary results of the primary consolidation settlements were estimated based on the consolidation properties of each sedimentary facies on the high-quality soil 




Figure 4. Diagram of estimation consolidation settlements by embankments at the VLM1 site as results in Table 1.

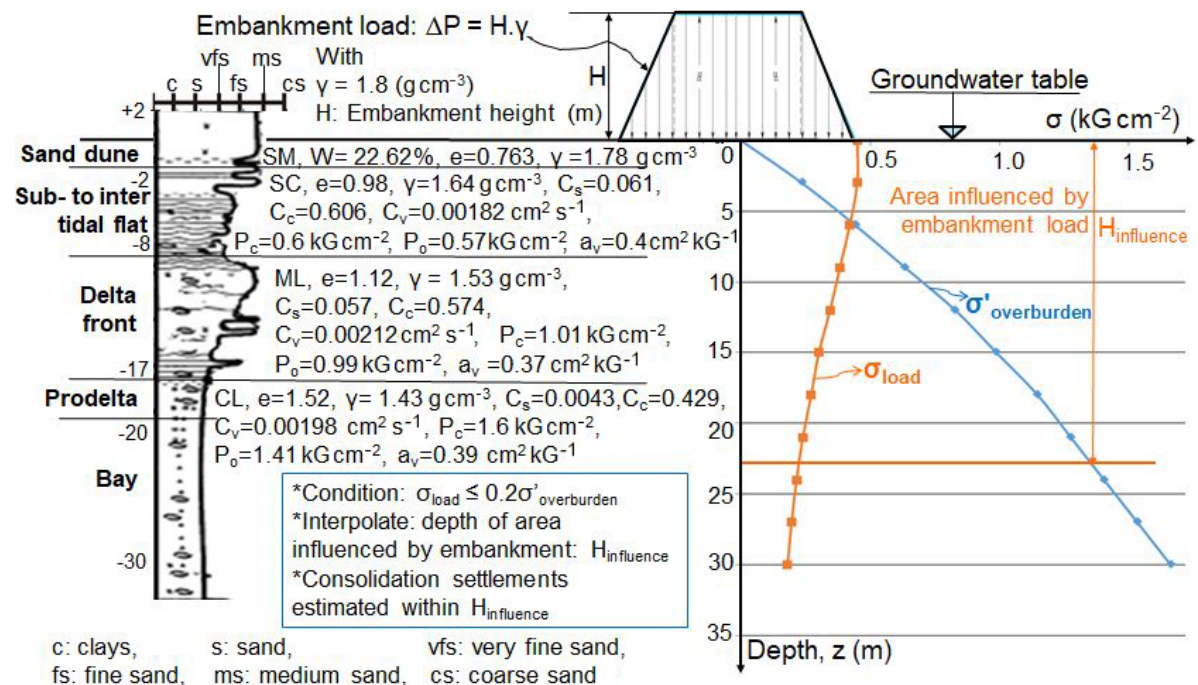

Figure 5. Diagram of estimation consolidation settlements by embankments at the BT2 site as in Table 2.

samples. The primary consolidation settlements were estimated at three investigation sites with the typical consolidation properties and geotechnical structures, and the diagrams for estimating the primary consolidation settlements by embankments at the VLM1and BT2 sites in the MD, and in District 2, Ho Chi Minh City (Figs. 4 and 5). The heights, $H$, of the embankments are as follows: in the MD the VLM1 and BT2 sites are 2.5 and $4 \mathrm{~m}$ high, and in the HCMC, $1.9 \mathrm{~m}$ high. The unit weight of soil in the embankments is $1.8 \mathrm{~g} \mathrm{~cm}^{-3}$. The soft soil grounds under the embankments in the MD and HCMC in this investigation were not improved before the construction of the embankments.

The magnitude of the primary consolidation settlement at the VLM1 site is the largest in comparison with those at the BT2 site and in District 2, HCMC. The soil at the BT2 site consists of sand dune and sub- to inter-tidal flat and delta front facies with high contents of sand in the upper part of the stratum (Fig. 5). The VLM1 site is in the upper delta plain and the BT2 site is in the lower delta plain (Ta et al., 2005). The upper delta plain was the tide-dominated delta and the lower delta plain was the tide- and wave-dominated delta (Fig. 1) (Ta et al., 2005). The MD Holocene delta evolution and depositional model (Ta et al., 2005) includes (1) the tide-dominated delta which is characterized by a coarseningupward succession from the open to inner bay, prodelta mud, and delta front and subtidal flat muddy sand, which is covered by the fining-upward succession of the muddy sub-tidal to inter-tidal flat facies, and (2) the tide- and wave-dominated delta which is characterized by coarser sediments and displays a typical coarsening-upward succession from prodelta to delta front and to foreshore facies. The facies successions in the lower delta plain consist of coarsening-upward from 
Table 1. Results of primary consolidation settlements for embankments with 2.5 and $4 \mathrm{~m}$ in height at the VLM1 site.

\begin{tabular}{|c|c|c|c|c|c|c|c|c|}
\hline $\begin{array}{l}\text { Sedimentary } \\
\text { faces }\end{array}$ & $\begin{array}{l}\text { Thickness } \\
(\mathrm{m})\end{array}$ & $\begin{array}{l}\text { Compression } \\
\text { index, Cc }\end{array}$ & $\begin{array}{l}\text { Swell } \\
\text { index, } C_{\mathrm{s}}\end{array}$ & $\begin{array}{l}\text { Initial void } \\
\text { ratio, } e_{0}\end{array}$ & $\begin{array}{l}\text { Coefficient } \\
\text { of consol- } \\
\text { idation, } C_{\mathrm{v}}\end{array}$ & $\begin{array}{l}\text { Effective } \\
\text { overburden } \\
\text { stress, } P_{0} \\
(\mathrm{kPa})\end{array}$ & $\begin{array}{l}\text { Settlement, } \\
S(\mathrm{~cm}) \\
\text { (by em- } \\
\text { bankment } \\
\text { height, } \\
H=2.5 \mathrm{~m} \text { ) }\end{array}$ & $\begin{array}{l}\text { Settlement, } \\
S(\mathrm{~cm}) \\
\text { (by em- } \\
\text { bankment } \\
\text { height, } \\
H=4 \mathrm{~m})\end{array}$ \\
\hline $\begin{array}{l}\text { Flood plain - } \\
\text { sub- to inter- } \\
\text { tidal flat } \\
(0-5.5 \mathrm{~m})\end{array}$ & 5.5 & 0.394 & 0.059 & 1.26 & 31.2 & 45.74 & 20.44 & 28.26 \\
\hline $\begin{array}{l}\text { Delta front } \\
(5.5-8.0 \mathrm{~m})\end{array}$ & 2.5 & 0.568 & 0.080 & 1.60 & 19.23 & 50 & 14.99 & 20.86 \\
\hline $\begin{array}{l}\text { Delta front } \\
(8.0-14.0 \mathrm{~m})\end{array}$ & 6 & 0.691 & 0.105 & 1.51 & 29.06 & 96 & 27.17 & 39.61 \\
\hline $\begin{array}{l}\text { Delta front } \\
(14.0-18.5 \mathrm{~m})\end{array}$ & 4.5 & 0.650 & 0.136 & 1.68 & 64.8 & 130 & 13.86 & 20.57 \\
\hline $\begin{array}{l}\text { Bay } \\
(18.5-25 \mathrm{~m})\end{array}$ & 6.5 & 0.685 & 0.116 & 1.55 & 5.85 & 168.25 & 17.69 & 26.61 \\
\hline $\begin{array}{l}\text { Estuary marine } \\
(25-27.8 \mathrm{~m})\end{array}$ & 2.8 & 0.599 & 0.093 & 1.33 & 9.1 & 183.5 & 6.74 & 10.18 \\
\hline $\begin{array}{l}\text { Marsh } \\
(27.8-31 \mathrm{~m})\end{array}$ & 3.2 & 0.575 & 0.087 & 1.16 & 29.75 & 218.95 & 6.81 & 10.36 \\
\hline $\begin{array}{l}\text { Marsh } \\
(31-35 \mathrm{~m})\end{array}$ & 4 & 0.532 & 0.069 & 1.12 & 26 & 250.226 & 7.09 & 10.85 \\
\hline $\begin{array}{l}\text { Marsh } \\
(35-41.5 \mathrm{~m})\end{array}$ & 6.5 & 0.832 & 0.076 & 1.42 & 46.6 & 284.492 & 13.98 & 21.49 \\
\hline $\begin{array}{l}\text { Estuary } \\
\text { channel } \\
(41.5-48 \mathrm{~m})\end{array}$ & 6.5 & 1.112 & 0.182 & 1.46 & 9.5 & 317.9 & 16.61 & 25.63 \\
\hline $\begin{array}{l}\text { Total } \\
\text { settlements }\end{array}$ & & & & & & & 145.37 & 214.42 \\
\hline
\end{tabular}

the delta front slope to subtidal flat, fining-upward sub-tidal to tidal flat, and coarsening-upward succession including foreshore-dune or fining-upward intertidal flat or salt marsh. In addition, the sediment falls within the tide- and wavedominated delta whose mechanical behavior sequence tends to be more cohesionless soils and strengths than those in the tide-dominated delta from the prodelta to sand dune facies (Truong et al., 2016). In District 2, HCMC, the sediments in the flood plain facies and marsh facies are cohesive soils; therefore, the primary consolidation settlements are large despite the limited height of the embankment $(1.9 \mathrm{~m})$.

The results of the primary consolidation settlements at the three investigation sites are very different, although the soils were all formed during the late Pleistocene-Holocene. Therefore, the standard construction-topography level for planning, management and control in the urbanization and construction could not be generally used for the MD and HCMC. At present, no standard procedure for management, planning and construction in the MD and HCMC exists.

\section{Conclusions}

The consolidation levels of the surface and deep sediment facies associations in the MD test sites are slight overconsolidation to heavy consolidation, the sediments having been subjected to strong dehydrating and oxidizing or aging and recrystallizing processes. The consolidation levels of the shallow sediment facies are normal consolidation to slight overconsolidation. 
Table 2. Results of primary consolidation settlements by embankments with 2.5 and $4 \mathrm{~m}$ in height at the BT2 site.

\begin{tabular}{|c|c|c|c|c|c|c|c|}
\hline $\begin{array}{l}\text { Sedimentary } \\
\text { faces }\end{array}$ & $\begin{array}{l}\text { Thickness } \\
\text { (m) }\end{array}$ & $\begin{array}{l}\text { Compression } \\
\text { index, } C_{\mathrm{c}}\end{array}$ & $\begin{array}{l}\text { Swell } \\
\text { index, } C_{\mathrm{s}}\end{array}$ & $\begin{array}{l}\text { Initial } \\
\text { void ratio, } \\
e_{0}\end{array}$ & $\begin{array}{l}\text { Effective } \\
\text { overburden } \\
\text { stress, } P_{0} \\
(\mathrm{kPa})\end{array}$ & $\begin{array}{l}S_{\mathrm{sc}}(\mathrm{cm}) \\
\text { (by em- } \\
\text { bankment } \\
\text { height, } \\
H=2.5 \mathrm{~m} \text { ) }\end{array}$ & $\begin{array}{l}S_{\mathrm{sc}}(\mathrm{cm}) \\
\text { (by em- } \\
\text { bankment } \\
\text { height, } \\
H=4 \mathrm{~m} \text { ) }\end{array}$ \\
\hline $\begin{array}{l}\text { Sub- to inter- } \\
\text { tidal flat } \\
(-2 \text { to }-8 \mathrm{~m})\end{array}$ & 10 & 0.6056 & 0.0606 & 0.981 & 57.1 & 50.40 & 87.2 \\
\hline $\begin{array}{l}\text { Delta front } \\
(-8 \text { to }-17 \mathrm{~m})\end{array}$ & 9 & 0.5736 & 0.0574 & 1.2 & 98.7 & 17.3 & 37.3 \\
\hline $\begin{array}{l}\text { Prodelta } \\
(-17 \text { to }-20 \mathrm{~m})\end{array}$ & 3 & 0.429 & 0.0429 & 1.42 & 140.8 & 6.7 & 39.3 \\
\hline $\begin{array}{l}\text { Total } \\
\text { settlements }\end{array}$ & & & & & & 25.14 & 55.34 \\
\hline
\end{tabular}

Table 3. Results of primary consolidation settlements by embankments with $1.9 \mathrm{~m}$ in height at District 2, Ho Chi Minh City, Vietnam.

\begin{tabular}{|c|c|c|c|c|c|c|c|c|}
\hline $\begin{array}{l}\text { Sedimentary } \\
\text { facies }\end{array}$ & $\begin{array}{l}\text { Thickness } \\
\text { of sublayer } \\
(\mathrm{cm})\end{array}$ & $\begin{array}{l}\text { Effective } \\
\text { overburden } \\
\text { stress, } P_{0} \\
(\mathrm{kPa})\end{array}$ & $\begin{array}{l}\text { Yield stress } \\
(\mathrm{kPa})\end{array}$ & $\begin{array}{l}\text { Initial void } \\
\text { ratio, } e_{0}\end{array}$ & $\begin{array}{l}\text { Compression } \\
\text { index, } C_{\mathrm{c}}\end{array}$ & $\begin{array}{l}\text { Swell } \\
\text { index, } C_{\mathrm{s}}\end{array}$ & $\begin{array}{l}\text { Influenced } \\
\text { load stress, } \\
\sigma_{\text {load }}(\mathrm{kPa})\end{array}$ & $\begin{array}{l}S_{\mathrm{sc}}(\mathrm{cm}) \\
\text { (by em- } \\
\text { bankment } \\
\text { height, } \\
H=1.9 \mathrm{~m} \text { ) }\end{array}$ \\
\hline \multirow[t]{6}{*}{ Flood } & 200 & 15.3 & 36.0 & 2.065 & 0.62 & 0.108 & 37.81 & 9.45 \\
\hline & 200 & 25.9 & 36.0 & 2.065 & 0.62 & 0.108 & 37.43 & 10.93 \\
\hline & 200 & 36.5 & 74.0 & 2.065 & 0.33 & 0.077 & 37.05 & 1.53 \\
\hline & 200 & 47.1 & 52.0 & 2.065 & 0.59 & 0.091 & 36.67 & 8.23 \\
\hline & 200 & 57.7 & 49.0 & 2.065 & 0.63 & 0.137 & 35.72 & 8.60 \\
\hline & 200 & 68.3 & 49.0 & 2.065 & 0.541 & 0.108 & 34.20 & 6.22 \\
\hline \multirow[t]{6}{*}{ Marsh } & 200 & 78.9 & 49.0 & 2.065 & 0.569 & 0.114 & 32.68 & 5.59 \\
\hline & 200 & 89.5 & 49.0 & 2.065 & 0.575 & 0.115 & 31.16 & 4.87 \\
\hline & 200 & 100.1 & 49.0 & 2.065 & 0.556 & 0.111 & 29.48 & 4.07 \\
\hline & 200 & 110.7 & 49.0 & 2.065 & 0.554 & 0.111 & 27.64 & 3.50 \\
\hline & 200 & 121.3 & 49.0 & 2.065 & 0.538 & 0.108 & 25.79 & 2.94 \\
\hline & 200 & 131.9 & 49.0 & 2.065 & 0.549 & 0.109 & 23.95 & 2.60 \\
\hline
\end{tabular}

None of the measured OCR values is less than 1 . The overconsolidation is due to the cementation, recrystallization, and ageing. Therefore, we should use the term yield stress ratio for the overconsolidation ratio and the term yield stress for the preconsolidation pressure for the MD late PleistoceneHolocene sediments.

The sediments in the upper delta plain with surface sedimentary facies being the flood plain facies and marsh facies lead to primary consolidation settlements which tend to be significantly higher than those in the lower delta plain with surface sedimentary facies being sand dune facies and subto inter-tidal flat facies.

Research is needed before a standard constructiontopography-level-based procedure can be set that integrates the characteristics of the consolidation settlements of the late Pleistocene-Holocene sediments under the man-made loads and the natural settlement by rapid depositional speed with the flood/ebb tides in the Mekong Delta and Ho Chi Minh City in the context of increase in sea level by global climatic change.

Data availability. Some or all data generated or used during the study are available from the corresponding author by request. 
Author contributions. MHT conceptualized the main idea of the paper. DTN prepared the figures. MHT and DTN wrote the paper. All authors read and approved the final draft.

Competing interests. The authors declare that they have no conflict of interest.

Special issue statement. This article is part of the special issue "TISOLS: the Tenth International Symposium On Land Subsidence - living with subsidence". It is a result of the Tenth International Symposium on Land Subsidence, Delft, the Netherlands, 17-21 May 2021.

Acknowledgements. The Civil Engineering Department, Tokyo Tech, and the Port and Airport Research Institute at Yokosuka, Japan, created favorable conditions to conduct the lab tests and collect documents. The authors would like to thank Vietnam National University HCMC under grant number C2018-18-22.

Financial support. This research has been supported by the Vietnam National University Ho Chi Minh City (VNU-HCM) (grant no. C2018-18-22).

\section{References}

Braja, M. D.: Principles of geotechnical engineering. Fourth Edition, International Thomson Publishing, 712 pp., 1998.

Burland, J. B.: On the compressibility and shear strength of natural clays, Geotechnique, 40, 329-378, 1990.

Head, K. H.: Soil classification and compaction tests, Vol. 1. Pentech press London, 1985a.

Head, K. H.: Permeability, Shear Strength and Compressibility Tests, Vol. 2. Pentech press London, 581-729, 1985 b.
Japan Geotechnical Society (JGS): Test method for one-dimentional consolidation properties of soils using constant rate of strain loading, JGS 0412, Laboratory Soil Testing Methods, JGS, 389414, 2000.

Lunne, T., Robertson, P. K., and Powell, J. J. M.: Cone Penetration Testing in Geotechnical Practice. Spon Press, Taylor and Fracis Group, London and New York, 312 pp., 1997.

Man, B. T.: Initial estimation consolidation characteristics of soft Mekong Delta clay for engineering practice, Proc. Intn. Workshop of Hanoi Geoengineering 2003 \& 2004, 37-49, 2003.

Ta, T. K. O., Nguyen, V. L., Tateishi, M., Kobayahi, I., Tanabe, S., and Saito, Y.: Holocene delta evolution and sediment discharge of the Mekong River, Southern Vietnam, Quaternary Sci. Rev., 21, 1807-1819, 2002a.

Ta, T. K. O., Nguyen, V. L., Tateishi, M., Kobayahi, I., Saito, Y., and Nakamura, T.: Sediment facies and Late Holocene progradation of the Mekong River Delta in Bentre Province, southern Vietnam: an example of evolution a tide-dominated to a tide- and wave-dominated delta, Sediment. Geol., 152, 313-325, 2002 b.

Ta, T. K. O., Nguyen, V. L., Tateishi, M., Kobayahi, I., and Saito, Y.: Holocene delta evolution and depositional models of the Mekong River Delta, Southern Vietnam, SEPM Special Publication No. 83, Copyright, SEPM (Society for Sedimentary Geology), ISBN 1-56576-113-8, 453-466, 2005.

Takemura, J., Watabe, Y., and Tanaka, M.: Characterization of alluvial deposits in Mekong Delta. Proc. Int. Workshop Characterization and Engineering Properties of Natural Soils, Vol. 3, 1805-1829, 2007.

Tran, K. T.: Sedimentology of the Mekong River Delta, Hochiminh City University published, 65 pp., 1993 (in Vietnamese).

Truong, M. H., Nguyen, V. L., Ta, T. K. O., and Takemura, J.: Changes in late Pleistocene-Holocene sedimentary facies of the Mekong River Delta and the influence of sedimentary environment on geotechnical engineering properties, Elsevier, Eng. Geol., 122, 146-159, 2011.

Truong, M. H., Nguyen, V. L., Ta, T. K. O., and Takemura, J.: The influence of delta formation mechanism on geotechnical property sequence of the late Pleistocene-Holocene sediments of the Mekong River Delta, Elsevier, Holiyon Geology, ISSN 24058440, vol. 2, issue 11, 2016. 